(2) Open Access Full Text Article

RAPID COMMUNICATION

\title{
Flow cytometric immunophenotyping of hematological malignancies: the way forward in Nigeria
}

This article was published in the following Dove Press journal:

Pathology and Laboratory Medicine International

30 June 2011

Number of times this article has been viewed

John Ayodele Olaniyi

Department of Hematology, University College Hospital, Ibadan, Nigeria
Correspondence: John Ayodele Olaniyi Department of Hematology University College Hospital, Ibadan, Nigeria

Tel +234802345 I509

Email ayodeleolaniyi8@gmail.com
Aim: This review serves to awaken the interest of stakeholders involved in research and management of hematological malignancies (HM) in the efficacy of flow cytometry in the immunophenotypic characterization of leukemias and lymphomas. This well-defined characterization plays a crucial role in diagnosis, classification, prognostic evaluation, and detection of minimal residual disease, in the context of clinical features and morphological diagnosis.

Methodology: Relevant literature was retrieved to highlight the principles of operation of flow cytometry, indications and applications, derivable clinical information and clinical relevance, sources of error, and necessary steps towards definitive and specific diagnosis of each HM.

Conclusion: Flow cytometric immunophenotyping (FCIMPT) of HM is highly demanding and capital intensive but its usefulness in profiling these exceptionally heterogeneous disorders, and allowing proper classification along the latest WHO classification guidelines, thereby paving the way for targeted therapy and clinical trial-driven management, significantly outweighs the cost, which can be fully recovered if properly managed. In a low-resource setting like Nigeria, limited immunohistochemistry serves to bridge the gap in technological advancement.

Keywords: flow cytometry, immunophenotyping, hematological malignancies, Nigeria

\section{Introduction}

Hematologic malignancies (HM) are a group of neoplasms that arise through malignant transformation of bone marrow derived cells. There is great diversity in this group of disorders reflecting the complexity of normal hemopoiesis. These malignancies are clonal disorders of hemopoietic stem cells whereby an abnormal clone of cells proliferates autonomously, suppressing normal hemopoiesis, and also infiltrates tissues and organs, thereby disturbing their normal physiological activities. The fundamental defect is believed to be due to a genetic aberration at the level of the hemopoietic stem cell.

$\mathrm{HM}$, traditionally regarded as leukemias, lymphomas and myeloma, are in fact exceptionally heterogeneous, with WHO classification (2008) system recognizing over 60 different clinical and pathological disease subtypes. This complexity is further reflected in widely varying clinical features, treatment pathways and outcome associated with these diseases. While some HM are acute and can be rapidly fatal, if untreated, many others are insidiously progressive and become chronic, leading to eventual death. The acute types are often malignancies emanating from precursor cells while the insidious ones are often malignancies arising from relatively or fully matured cells. 


\section{Historical background and current diagnostic competency in Nigeria Historical perspective}

Limited or low technology immunophenotyping (IMPT) was carried out at the University College Hospital, Ibadan in the early 1980 s by Williams et al ${ }^{1}$ using very simple and cheap methods to characterize hemopoietic cells. Using the first generation of monoclonal antibodies that were emerging at that time, as well as modified indirect immunofluorescence microscopy, the first case of adult $\mathrm{T}$ cell lymphoma leukemia (ATLL) was described in Africa. ${ }^{1}$ However, over years of economic downturn, even limited immunohistochemistry (IHC) became unavailable until hematologists/pathologists in the diaspora came to our aid.

\section{Current status of IMPT in Ibadan Nigeria}

Records show that the first immunohistology service was established in 2004 at the surgical research laboratory of Dr. Clement Adebamowo and collaborators; ${ }^{2,3}$ however, minimal immunohistochemical studies were previously undertaken. ${ }^{4,5}$ In the last two years, immunohistochemistry started emerging in Ibadan, Nigeria through the collaborative effort of Nigerians in diaspora, eg, the efforts of the Global Health Initiative through Professor Olufunmilayo Olopade of the University of Chicago and also the Aboderin Foundation Fund, which was provided by a Nigerian philanthropist. In this instance, the most important and relevant monoclonal antibodies for each particular disease were identified and utilized. This goes a long way toward confirming diagnosis in controversial histology reports and in determining the need for targeted therapy, eg, rituximab.

Although advances in science and technology have created techniques for the molecular diagnosis of most of these HM in the developed world, in Nigeria and probably most of Africa, the diagnosis of HM has remained at a rudimentary level because we failed to carefully define our priorities. Therefore, clinical features, morphology and occasionally limited immunohistochemistry remain our mainstay in diagnosing HM.

Flow cytometry (FC) is a very robust and effective method for the diagnosis of HM and hence FCIMPT of HM is the most relevant clinical application of flow cytometry.

IMPT of abnormal hematological cells is very useful for the diagnosis, classification, prognostic evaluation and detection of residual disease in patients with HM. ${ }^{6-10}$ The procedure evolved over the last two decades from microscopic evaluation of antibody staining to flow cytometry, which is now recognized as the preferred method for data analysis. ${ }^{8-13}$

For Nigeria to meet the millennium development goals in health programs in general and specifically in the management of HM, a giant stride will have to be taken not only to improve manpower development in cancer diagnosis and treatment but also in equipping our specialist hospitals with modern equipment of which flow cytometry is one part. All requirements for efficient and continuous functioning of such equipment will also have to be provided.

This review discusses the principle of operation and usefulness of FC, and also follows the WHO classification to discuss the immunophenotypic characteristics of common HM found in Nigeria.

\section{What information can be provided by FCIMPT on HM?}

FCIMPT helps to give precise immunophenotypic characteristics of pathological hemopoietic cells. Leukemic/ lymphomatous cells reflect immunophenotypic characteristics of healthy cells blocked at a certain stage of differentiation. Malignant blood cells display different aberrant phenotypes as defined by cross-lineage antigen expression; asynchronous antigen expression; ectopic phenotypes; and abnormal differentiation pathways, among others.

Multiple accumulated data have shown increased incidence of these aberrant phenotypes in acute leukemias, ${ }^{14-21}$ chronic lymphoproliferative disorders ${ }^{22}$ and plasma cell dyscrasias, ${ }^{23,24}$ which allows for discrimination between healthy cells and pathological cells within a sample. FCIMPT basically performs the following activities.

\section{Enumeration of leukemic cells}

The number of pathological cells identified morphologically in the bone marrow/peripheral blood samples is currently used for the diagnosis of several conditions. Diagnostic criteria based on the proportion of blasts in several conditions like myelodysplastic syndrome ${ }^{25}$ or acute leukemia; ${ }^{26}$ the percentage of plasma cells in plasma cell dyscrasia, ${ }^{27}$ and the number of mature-appearing lymphocytes in chronic lymphocytic disorders ${ }^{28}$ are used, based on morphology and cytochemistry. Just as FC is useful in the diagnostic laboratory for the enumeration of CD4 T-lymphocytes in HIV infection, it has also become the preferred method to assess the number of hemopoietic progenitor cells (CD34+ cells) in cell products that will be used for bone marrow or peripheral 
blood stem cell transplantation. ${ }^{29}$ In this application, FC has been shown to be a robust and reproducible technology. ${ }^{30-32}$ Immunophenotypic enumeration of leukemic cells has both diagnostic and prognostic value.

\section{Characterization of leukemic cells}

After identification and enumeration of pathological cells, immunological characterization is carried out in terms of (i) lineage assignment; (ii) analysis of degree of heterogeneity of the abnormal cell population attributable to either the existence of different pathological clones or the presence of cells in different maturation stages; and (iii) further phenotypic characterization of each of the pathological cell subsets identified.

\section{The principles of FC}

FC uses the principles of light scattering, light excitation and emission of fluorochrome molecules to generate specific multiparameter data from particles and cells in the size range of $0.5 \mu \mathrm{m}$ to $40 \mu \mathrm{m}$ diameter. The cells are hydrodynamically focused in a sheath of phosphate buffer saline before intercepting an optimally focused light source. Lasers are most often used as light source in FC.

As the cells of interest intercept light, they scatter it, and fluorochromes are excited to a high energy state. This energy is released as photons of light with specific spectral properties unique to different fluorochromes.

One unique feature of $\mathrm{FC}$ is that it measures fluorescence per cell or particle. This contrasts with spectrophotometry in which the percent absorption and transmission of specific wave lengths of light is measured for a bulk volume of sample.

The scattered and emitted light from cells and particles are converted to electrical pulses by optical detectors. Collimated light is picked up by confocal lenses focused at the interception point of the cells and the light source. Light is sent to different detectors by using optical filters. For example a $525 \mathrm{~nm}$ band-pass filter placed in the light path prior to the detector will allow only green light to pass into the detector. The most common type of detector used in flow cytometry is the photomultiplier tube (PMT).

The electrical pulses originating from light detected by the PMT are then processed by a series of linear and log amplifiers. Logarithmic amplification is most often used to measure fluorescence in cells. This type of amplification expands the scales for weak signals and compresses the scale for strong or specific fluorescence signals.
After the different signals or pulses are amplified they are processed by an analog to digital converter which in turn allows for events to be plotted on a graphical scale.

FC data outputs are stored in the form of computer files using FCS 2.0 or 3.0 standards. Data corresponding to one sample can be stored as a list mode file and/or histogram file.

The Beckman Coulter XL (Beckmann Coulter SA Pty Ltd, Growthpoint Business Park, Midrand, South Africa) instruments are bench-top, flow cytometer analyzers. They are capable of acquiring multiparameter FC data but they cannot separate or purify cells. Sorting is a specialized process that requires sophisticated electronic components not incorporated into most bench-top instruments. The Beckman-Coulter ELITE-ESP and Dako-CyomationMoFli high speed sorters (University of California, Berkeley, CA) are representative research grade cell sorters. Sorters include the following components: a turnable transducer which permits the breaking of the fluid sheath into individual droplets, which will encapsulate single cells; electric charge delays for charging individual droplets; deflection plates for deflecting individual charged droplets into collection tubes; and software settings for defining sorting criteria.

FC has undergone major technical advances to provide high sensitivity and specificity through improved instrumentation, introduction of new monoclonal antibodies, utilization of "up to 6 color staining," permeabilizing agents, and CD45 gating strategies.

Pre-analytical factors for blood and bone marrow samples are that: (a) anticoagulant (EDTA or heparin) be used; (b) the specimen is analyzed within 24 hours; (c) storage should be at $2{ }^{\circ} \mathrm{C}-20^{\circ} \mathrm{C}$; (d) there is no need to isolate mononuclear cells; and (e) great care be taken with lysing procedures.

It is recommended that immunophenotyping should be assessed in conjunction with clinical features and cell morphology with strict adherence to quality system essentials, and careful selection of fluorochromes: antibodies whose normal expression is rather $\operatorname{dim}(\mathrm{eg}, \mathrm{CD} 7, \mathrm{CD} 10, \mathrm{CD} 11 \mathrm{~b}$, CD13, CD2, CD34, CD64, CD117 or Tdt) should be labeled with the brightest fluorochromes like phycoerythrin and, if instrumentation allows, allophycocyanin.

Extensive studies ${ }^{6-12,33-37}$ have been done on the factors that affect the results of immunophenotyping, including:

1. The type and quality of samples.

2. The reagent and sample preparation protocols.

3. Instrument set-up and calibration.

4. Potential components of subjectivity introduced during data analysis or with the interpretation of the results represent the most common sources of variability. 


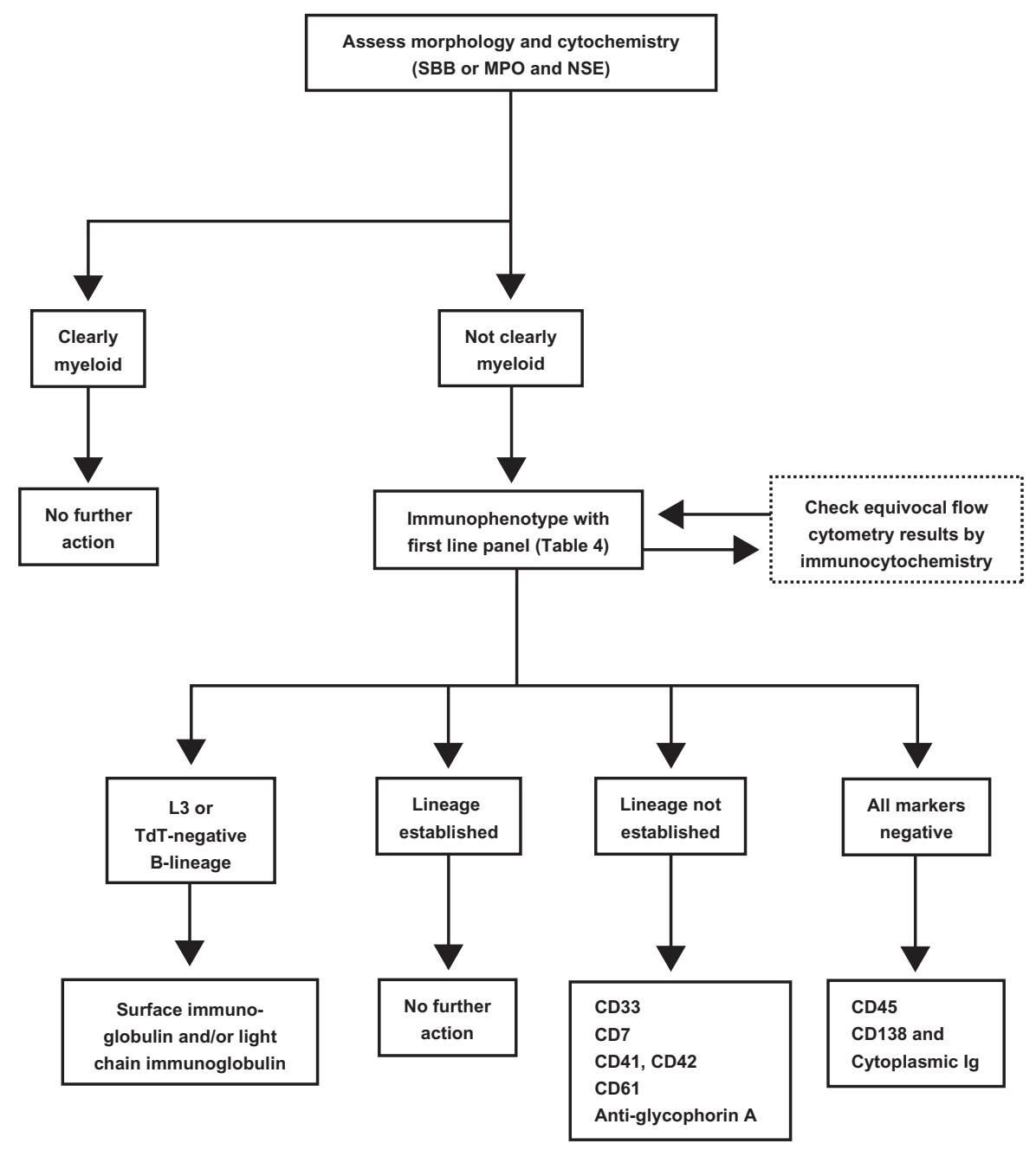

Figure I Flow chart for the diagnosis of acute leukemia.

Note: Reproduced from NewBU. ${ }^{65}$

Abbreviations: MPO, myeloperoxidase; NSE, nonspecific esterases; SBB, Sudan Black B.
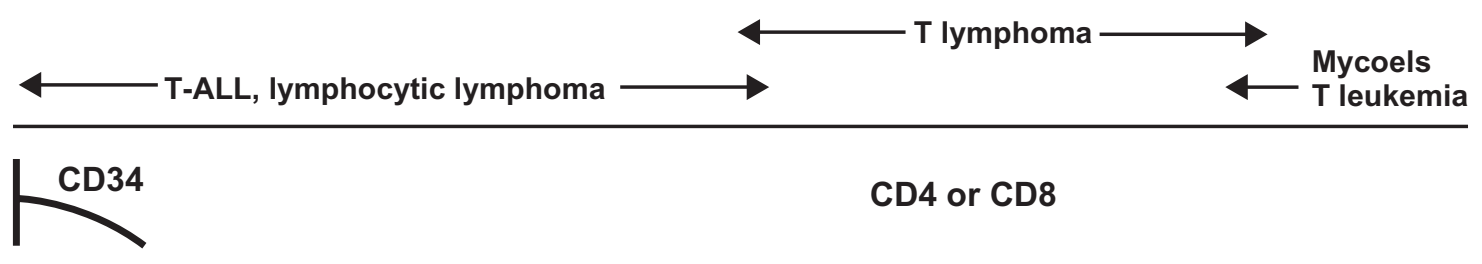

CD4 or CD8

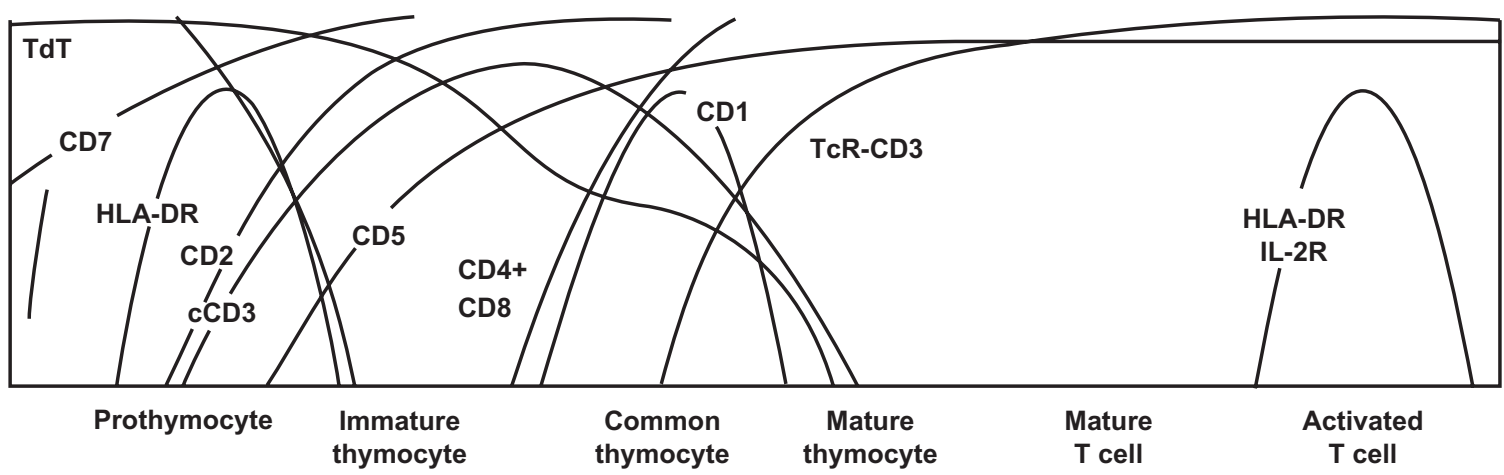

Figure 2 T-acute lymphoblastic leukemia (ALL): lymphocyte development. Note: Reproduced from NewBU.65 


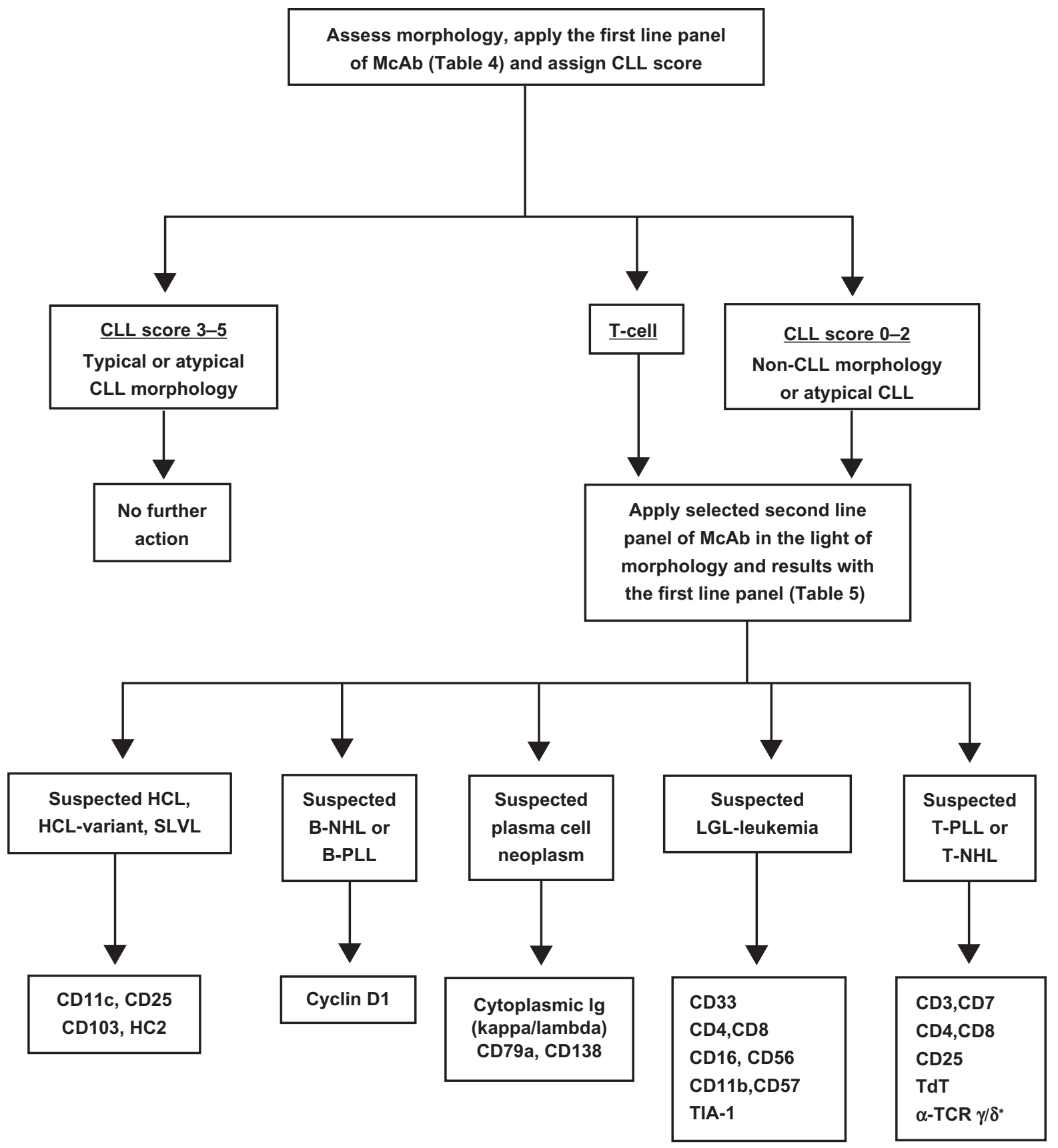

Figure 3 Flow chart for the diagnosis of chronic lymphoproliferative disorders.

Note: Reproduced from NewBU. ${ }^{65}$

Abbreviations: NHL, B-non-Hodgkin's lymphoma; PLL, B-prolymphocytic leukemia; CLL, chronic lymphocytic leukemia; HCL, hairy cell leukemia; LGL, large granular lymphocyte; McAb, monoclonal antibody; SLVL, splenic lymphoma with villous lymphocyte; T-PLL, T-prolymphocytic leukemia; T-NHL, non-Hodgkin's lymphoma.

\section{The clinical application of FC}

The clinical applications of FCIMPT include the diagnosis and subtyping of lymphoproliferative disorders and leukemias; detection of residual disease in the above mentioned; CD34 assays; determination of lymphocyte subsets; paroxysmal nocturnal hemoglobinuria (PNH) studies; fetal-maternal hemorrhage; DNA ploidy; apoptosis; and platelet aggregation.
To date, the clinical utility of the FCIMPT characterization of hematological malignancies has been based mainly on the investigation of the similarities between leukemic and healthy cells. ${ }^{6-12,33,34}$ Assessments of the lineage and differentiation stage of the pathology represent the basis of current IMPT diagnosis and classification of hematological malignancies. It is however well established that leukemic cells display immunophenotypic features that are different from those present in healthy cells 
of the same cell lineage and maturation stage. $15,16,18,23,24,32,38-41$ Most probably these phenotypic aberrations are related to the existence of leukemic cells with underlying genetic aberrations. In support of the fact that specific genetic abnormalities are associated with characteristic phenotypic aberrations, many reports have shown this link between specific genetic alterations and the immunophenotic characteristics of leukemic cells in both acute myeloblastic leukemia (AML) ${ }^{42-54}$ and acute lymphoblastic leukemia (ALL). ${ }^{55-60}$ However immunophenotyping cannot be used as a screening method to select cases carrying specific genetic abnormalities because the sensitivity and specificity of detection of aberrant immunophenotypes is poor. This may be related to technical issues.

\section{Lineage assignment of pathological cells}

1. Mature (chronic hematologic malignancies): express highly specific markers such as CD3/TCR complex in T cell disorders. ${ }^{6-11,130}$

2. In acute leukemia, there is a major challenge because of the immaturity of the cells.

Cross-lineage expression: lymphoid markers TdT, $\mathrm{CD} 2, \mathrm{CD} 7$ and CD19 was demonstrated in MPO+ myeloid leukemic cells. ${ }^{61-64}$ Positivity for myeloid antigens CD13, $\mathrm{CD} 33$ and $\mathrm{CD} 15$ can be found in a variable proportion of ALL cases. ${ }^{55,59,64}$

Incidence of real biphenotypic/bilineage cases is very low.

3. The specific markers for cells of the B lymphoid lineage are cytoplasmic CD79a and either surface or cytoplasmic immunoglobulin.

4. For T cell lineage the most specific markers are cytoplasmic or surface $\mathrm{CD} 3$ and $\mathrm{T}$ cell receptor (TCR). ${ }^{7-12}$

5. For myeloid cells, MPO+ and lysozyme are the most highly specific markers. ${ }^{8,12,33,39}$

6. Myeloblast subclassification into different myeloid cell lineages largely remains a challenge for the future.

Table I Panels of antibodies for the scoring system for biphenotypic acute leukemia

\begin{tabular}{llll}
\hline Score & B-Lymphoid & T-Lymphoid & Myeloid \\
\hline 2 & CD79a & CD3 & MPO \\
& CCD22 & TC Ralpha/beta & \\
& clgM & & \\
I & CD19 & CD2 & CDI17 \\
& CD20 & CD5 & CDI3 \\
& CD10 & CD8 & CD33 \\
& & CD 10 & CD65 \\
0.5 & TdT & TdT & CDI4 \\
& CD34 & CD7 & CD 15 \\
\hline
\end{tabular}

Abbreviation: TCR, T-cell receptor.
Table 2 Diagnosis of acute leukemias (B-ALL subtypes)

\begin{tabular}{|c|c|c|c|c|}
\hline & $\begin{array}{l}\text { Precursor } \\
\text { B-ALL }\end{array}$ & $\begin{array}{l}\text { Common } \\
\text { ALL }\end{array}$ & $\begin{array}{l}\text { Pre-B- } \\
\text { ALL }\end{array}$ & $\begin{array}{l}\text { Mature-B- } \\
\text { ALL }\end{array}$ \\
\hline HLA-DR & \multirow{4}{*}{\multicolumn{4}{|c|}{ Positive }} \\
\hline cCD22 & & & & \\
\hline CD79a & & & & \\
\hline CDI9 & & & & \\
\hline$\overline{\mathrm{TdT}}$ & \multicolumn{3}{|c|}{ Positive } & Negative \\
\hline CDI0 & Negative & \multicolumn{2}{|c|}{ Positive } & Negative \\
\hline clgM & & ative & Positive & Negative \\
\hline slg & \multicolumn{3}{|c|}{ Negative } & Positive \\
\hline
\end{tabular}

Note: Reproduced from NewBU. ${ }^{65}$

Abbreviations: ALL, acute lymphoblastic leukemia; B-ALL, B-acute lymphoblastic leukemia.

However, megakaryocyte-associated markers (CD61, CD41 and CD42), ${ }^{12,33,39,45}$ and erythroid-related glycophorin $\mathrm{A}^{12,33,39}$ are already well defined. No good markers have been identified from discriminating granulocytic from monocytic cells.

\section{Diagnosis of acute leukemia}

The strategy for leukemia IMPT includes the following: identify blasts/abnormal cells; determine lineage (B, T-lymphoid or myeloid); determine immunological subtype; search for leukemia aberrant phenotypes; and customize follow up panel for minimal residual disease.

Figures 1, 2 and 3, and Tables 1, 2, 3 and 4 clearly summarize the diagnostic pattern of hematological malignancies with the aid of flow cytometry.

\section{Conclusion}

FCIMPT of hematological malignancies has become indispensable in view of its role in clearly defining the complex hemopoietic malignancies according to lineage and maturation stage, using differentiation markers. It is also fast, sensitive and specific. It appears expensive to maintain, but careful planning, including having a regional center to start with, along

Table 3 Diagnosis of acute leukemia (T-ALL subtypes)

\begin{tabular}{|c|c|c|c|c|}
\hline & $\begin{array}{l}\text { Pro- } \\
\text { T-ALL }\end{array}$ & $\begin{array}{l}\text { Pre- } \\
\text { T-ALL }\end{array}$ & $\begin{array}{l}\text { Cortical- } \\
\text { T-ALL }\end{array}$ & $\begin{array}{l}\text { Mature- } \\
\text { T-ALL }\end{array}$ \\
\hline $\mathrm{TdT}$ & \multicolumn{3}{|c|}{ Positive } & Negative \\
\hline cCD3 & \multicolumn{4}{|c|}{ Positive } \\
\hline$\overline{\text { CD7 }}$ & \multicolumn{4}{|c|}{ Positive } \\
\hline CD2 & Negative & \multicolumn{3}{|c|}{ Positive } \\
\hline$\overline{\text { CD5 }}$ & Negative & \multicolumn{3}{|c|}{ Positive } \\
\hline CD4 & \multicolumn{2}{|c|}{ Negative } & Positive for & Positive for \\
\hline CD8 & \multicolumn{2}{|c|}{ Negative } & $\begin{array}{l}\text { CD4 and } \\
\text { CD8 }\end{array}$ & $\begin{array}{l}\text { CD4 or } \\
\text { CD8 }\end{array}$ \\
\hline$\overline{C D I a}$ & \multicolumn{2}{|c|}{ Negative } & Positive & Negative \\
\hline sCD3 & \multicolumn{2}{|c|}{ Negative } & & Positive \\
\hline
\end{tabular}

Note: Reproduced from NewBU. ${ }^{65}$

Abbreviation: T-ALL, T-acute lymphoblastic leukemia. 
Table 4 Panel of markers for the diagnosis of chronic/matured lymphoproliferative disorders

\begin{tabular}{|c|c|c|c|c|}
\hline \multirow[t]{2}{*}{ First line } & B cell & T cell & $B$ and $T$ cel & \\
\hline & $\begin{array}{l}\text { CD19 } \\
\text { CD23, FMC7 } \\
\text { Smlg } \\
\text { (kappa/lambda) } \\
\text { CD22, CD79b }\end{array}$ & CD2 & CD5 & \\
\hline \multirow[t]{2}{*}{ Second line } & $\begin{array}{l}\text { I } \\
\text { CDIIc, CD25 }\end{array}$ & $\begin{array}{l}\text { II } \\
\text { Cytlg } \\
\text { (kappa/lambda) }\end{array}$ & $\begin{array}{l}\text { III } \\
\text { CD3, CD7 }\end{array}$ & $\begin{array}{l}\text { IV } \\
\text { Cyclin DI }\end{array}$ \\
\hline & CDI03, HC2 & $\begin{array}{l}\text { CD79a, } \\
\text { CDI38 }\end{array}$ & $\begin{array}{l}\text { CD4, CD8 } \\
\text { CD25 }\end{array}$ & \\
\hline
\end{tabular}

Note: Reproduced from NewBU.65

with meticulous management, coupled with its wide benefit will offset the cost. It is high time to make a seismic change in the management of hematological malignancies in Nigeria.

\section{Acknowledgments}

The author acknowledges with gratitude the support of the UICC and Global Health Initiative of University of Chicago for the joint scholarship awarded to study flow cytometry immunophenotyping at the University of Chicago and also thanks Professor Olufunmilayo Olopade for providing the enabling environment and Professor CKO Williams for his advice on the manuscript.

\section{Disclosure}

The author reports no conflicts of interest in this work.

\section{References}

1. Williams CKO, Saxinger C, Alabi GO, et al. Human T cell leukaemia virus-associated lymphoproliferative disease: report of two cases in Nigeria. Br Med J. 1984;288(6429):1495-1496.

2. Akang EE. Recent methods and techniques in diagnostic histopathology: the impact on tropical pathology practice. Annals of Tropical Pathology. 2010;1:7-15.

3. Adebamowo CA, Famooto A, Ogundiran TO, Aniagwu T, Nkwodimmah C, Akang EE. Immunohistochemical and molecular subtypes of breast cancer in Nigeria. Breast Cancer Res Treat. 2008; 110(1):183-188.

4. Thomas JO, Rafindadi A, Heyyet A, Jones M, Gatter KC, Manson DY. Immunophenotyping of Nigerian cases of non-Hodgkins lymphoma on paraffin sections. Histopathology. 1991;18(6):505-510.

5. Thomas JO, Olu-Eddo AN. Immunohistochemistry in the diagnosis of small blue cell tumors of childhood. West Afr J Med. 2006;25(3): 199-204.

6. Davis BH, Foucar K, Szczkowski W, et al. US-Canadian consensus recommendation in the immunophenotypic analysis of hematologic neoplasia by flow cytometry: medical indications. Cytometry. 1997; 30(5):249-263.

7. Jennings CD, Foon KA. Recent advances in flow cytometry: application to the diagnosis of hematologic malignancy. Blood. 1997;90(8): 2863-2892.

8. Lanza F. Towards standardization in immunophenotyping hematological malignancies. How can we improve the reproducibility and comparability of flow cytometric results? Working Group on Leukemia Immunophenotyping. Eur J Histochem. 1996;40 Suppl 1:7-14.
9. Rothe G, Schmitz G. Consensus protocol for the flowcytometry immunophenotyping of hematologic malignancies. Working Group on Flow Cytometric and Image analysis. Leukemia. 1996;10(5): 877-895.

10. Ruiz Arguelles A, Dugue RE, Orfao A. Report on the first Latin American consensus conference on flow cytometric immunophenotyping of leukaemia. Cytometry. 1998;34(1):39-42.

11. Braylan RC, Borowitz MJ, Davis BH, Stelzer GT, Steward CC. USCanadian consensus recommendation on the immunophenotypic recommendations of hematologic neoplasia by flow cytometry. Cytometry. 1997; 30(5):213.

12. General Haematology Task Force of BCSH. Immunophenotyping in the diagnosis of acute leukaemias. J Clin Pathol. 1994;47(9):777-781.

13. General Haematology Task Force of BCSH. Immunophenotyping in the diagnosis of chronic lymphoproliferative disorders. J Clin Pathol. 1994;47(10):871-875.

14. Batata A, Shen B. Immunophenotyping of subtypes of B-chronic (mature) lymphoid leukemia. A study of 242 cases. Cancer. 1992; 70(10):2436-2443.

15. Bogen S, Pelly D, Charif M, et al. Immunophenotypic identification of Sezary cells in peripheral blood. Am J Clin Pathol. 1996;106(6): 739-748.

16. Catovsky D. Chronic lymphoproliferative disorders. Curr Opin Oncol. 1995;7(1):3-11.

17. Cheson B, Bennet J, Grover M, et al. National Cancer Institute-sponsored working group guidelines for chronic lymphocytic leukemia: revised guidelines for diagnosis and treatment. Blood. 1996;87(12): 4990-4997.

18. Emile JF, Bouliand ML, Haloun C, et al. CD5- CD56+ T-cell receptor silent peripheral T-cell lymphomas are natural killer cell lymphomas. Blood. 1996;87(4):1466-1473.

19. Geisler C, Larsen J, Hansen N, et al. Prognostic importance of flow cytometric immunophenotyping of 540 consecutive patients with B-cell chronic lymphocytic leukemia. Blood. 1991;78(7):1795-1802.

20. Harris NL, Jaffe ES, Stein H, et al. A revised European-American classification of lymphoid neoplasms: aproposal from the International Lymphoma Study Group. Blood. 1994;84(5):1361-1392.

21. Hoyer J, Ross C, Li CY, et al. True T-cell chronic lymphocytic leukemia: a morphologic and immunophenotypic study of 25 cases. Blood. 1995; 86(3):1163-1169.

22. Kilo MN, Dorfman DM. The utility of flow cytometric immunophenotypic analysis in the distinction of small lymphocytic leukemia from mantle cell lymphoma. Blood. 1996;105(4):451-457.

23. Macon W, Williams M, Greer J, et al. Natural killer-like T-cell lymphomas suggestive of lymphoma of T-large granular lymphocytes. Blood. 1996;87(4);1474-1483.

24. Manutes E, Catosky D. CLL should be used only for the disease with B cell phenotype. Leukemia. 1993;7(6):917-918.

25. Manutes E, Catosky D, Mature T-cell leukaemia lymphoma syndromes. Review of our experience in 175 cases. Leuk Lymphoma. 1991;4: 81-89.

26. Matutes E, Owosu-Ankomah K, Morilla R, Garcia Marco J, Houlihan A, Catovsky D. The immunologic profile of B-cell disorders and proposal of a scoring system for the diagnosis of CLL. Leukemia. 1994;8(10):1640-1645.

27. Rozman C, Montserrat E. Chronic lymphocytic leukemia. $N$ Engl $J$ Med. 1995;333(16):1052-1057.

28. Sememzato G, Zambello R, Starkebaum G, Oshimi K, Loughran T. The lymphoproliferative disease of granular lymphocytes: updated criteria for diagnosis. Blood. 1997;89(1):256-260.

29. Tbakhi A, Edinger M, Myles J, Pohlman B, Tubbs R. Flow cytometric immunophenotyping of non-Hodgkin's lymphoma and related disorders. Cytometry. 1996;25(2):113-124.

30. The Non-Hodgkin's Lymphoma Classification Project. A clinical evaluation of the International Lymphoma Study Group classification of non-Hodgkin's lymphoma. Blood. 1997;89(11):3909-3918.

31. Yamada Y. Phenotypic and functional analysis of leukemic cells from 16 patients with adult T-cell leukemia/lymphoma. Blood. 1983;61(1): 192-199. 
32. Zuckerberg LR, Medeiros LJ, Ferry JA, Harris NL. Diffuse low-grade B-cell lymphomas. Four clinically distinct subtypes defined by a combination of morphologic and immunophenotypic features. Am J Clin Pathol. 1993;100(4):373-385.

33. Bene MC, Castoldi G, Knapp W, et al. Proposals for the immunological classification of acute leukaemias. European group for the Immunological Characterization of Leukaemias (EGIL). Leukemia. 1995;9(10): 1783-1786.

34. Hanson C, Abaza M, Sheldon S, Ross C, Schnitzer B, Stoolman L. Acute biphenotypicleukaemia: immunophenotypic and cytogenetic analysis. Br J Haematol. 1995;84(1):49-60.

35. Jannosy G, Coustan-Smith E, Campana D. The reliability of cytoplasmic CD3 and CD22 antigen expression in the immunodiagnosis of acute leukemia: a study of 500 cases. Leukemia. 1989;3(3):170-181.

36. Launder T, Bray R, Stempora L, Chenggis ML, Farhi DC. Lymphoidassociated antigen expression by acute myeloid leukemia. Am J Clin Pathol. 1996;106(2):185-191.

37. San Miguel JF, Martinez A, Macedo A, et al. Immunophenotyping investigation of minimal residual disease is a useful approach for predicting relapse in acute myeloid leukaemiapatients. Blood. 1997;90(6):2465-2470.

38. Urbano-Ispizua A, Cervantes F, Matutes E, et al. Immunophenotypic characteristics of blast crisis of chronic myeloid leukemia: correlations with clinico-biological features and survival. Leukemia. 1993; 7(9):1349-1354.

39. Borwitz MJ, Bray R, Gascoyne R, et al. US-Canadian consensus recommendations on the immunophenotypic analysis of hematologic neoplasia by flow cytometry data: analysis and interpretation. Cytometry. 1997;30(5):236-244.

40. Borowitz MJ, Guenther KL, Shults KE, Stelzer GT. Immunophenotyping of acute leukaemia by flow cytometric analysis. Use of CD45 and right-angle light scatter to gate on leukemic blasts in three-color analysis. Am J Clin Pathol. 1993;100(5):543-540.

41. Hurwitz CA, Loken MR, Graham ML, et al. Asynchronous antigen expression in B lineage acute lymphoblastic leukemia. Blood. 1988;72(1):299-307.

42. Foon KA, Todd RF. Immunologic classification of leukemia and lymphoma. Blood. 1986;68(1):1-31.

43. Bennett JM, Catovsky D, Daniel MT, et al. Proposal for the recognition of minimally differentiated acute myeloid leukaemia (AML-M0). Br J Haematol. 1991;78(3):325-329.

44. Paietta E, Andersen J, Wernick P. A new approach to analyzing the utility of immunophenotyping for predicting clinical outcome in acute leukemia. Eastern Cooperative Oncology Group. Leukemia. 1996;10(1):1-4.

45. San Miguel JF, Gonzalez M, Canizo MC, et al. Leukemias with megakaryoblastic involvement: clinical hematologic and immunologic characteristics. Blood. 1988;72(2):402-407.

46. San Miguel JF, Gonzalez M, Canizo MC, Anta JP, Zola H, Lopez Borrasca A. Surface marker analysis in acute myeloid leukaemia and correlation with FAB classification. Br J Haematol. 1986;64(3):547-560.

47. Bene MC, Bernier M, Castoldi G, et al. Impact of immunophenotyping on management of acute leukemias. Haematologica. 1999;84(11): 1024-1034.

48. Montserrat E. Chronic lymphoproliferative disorders. Curr Opin Oncol. 1997;9(1):34-41.
49. San Miguel JF, Almeida J, Orfao A. Laboratory investigations. In: Mehta J. editor. Myeloma. Oxford: ISIS Medical Media. 1999: 234-268.

50. Letwin B, Wallace P, Muirhead K, Hensler W, Kashatus W, Horan P. An improved clonal excess assay using flow cytometry and B cell gating. Blood. 1990;75:1178-1185.

51. Orfao A, Almeida J, Sanchez ML, Sanchez-Guijo F, Vallejo C, Lopez-Berges $\mathrm{MC}$, et al. Incidence of aberrant phenotypes in a large series of B cell chronic lymphoproliferative disorders. Implications for minimal residual disease. Cytometry. 1998;(Supp1 9):53.

52. Sharp P, Joshi S, Armitage J, et al. Significance of detection of occult non-Hodgkin's lymphoma in histologically non-involved bone marrow by a culture technique. Blood. 1992;79(4):1074-1080.

53. Campana D, Pui CH. Detection of minimal residual disease in acute leukemia: methodologic advances and clinical significance. Blood. 1995;85(6):1416-1434.

54. Campana D, Yokota S, Coustan-Smith E, Hansen-Hagge TE, Janossy G, Bartram CR. The detection of acute lymphoblastic leukemia cells with immunologic methods and polymerase chain reaction: a comparative study. Leukemia. 1990;4(9):609-614.

55. Ciudad J, Sau-Miguel JF, Lopez-Berges MC, et al. Prognostic value of immunophenotypic detection of minimal residual disease in acute lymphoblastic leukemia. J Clin Oncol. 1998;16(12):3774-3781.

56. Orfao A, Cludad J, Lopez-Berges MC, et al. Acute lymphoblastic leukemia (ALL): detection of minimal residual disease (MRD) at flow cytometry. Leuk Lymphoma.1994;13 Suppl 1:87-90.

57. San Miguel JF, Gonzalez M, Orfao A. Minimal residual disease in acute myeloid malignancies. In Degos L, Herman F, Linch D, Lowenberg D, editors. Text book of malignant hematology. London: Martin Dunitz. 1998:871-891.

58. Van Dongen JJM, Bartram CR, Worman B, Biondi A, Orfao A, San Miguel JF. Detection of minimal residual disease (MRD) in acute leukaemia (AL). Trends Oncol Hematol. 1995;3:54-58.

59. Worman B, Griesinger F, Innig G, Kolkmeyer A, Toepken S, Grove D, et al. Detection of minimal leukaemic cells in patients with acute myeloid leukemia based on cell surface antigen expression. Sangre (Barc). 1992;37(2):133-135.

60. Bradstock KF, Kirk J, Grimsley PG, Kabral A, Hughes WG. Unusual immunophenotypes in acute leukaemias: incidence and clinical correlations. Br J Haematol. 1989;72(4):512-518.

61. Campana D, Coustan-Smith E, Behn FG. The definition of remission in acute leukemia with immunological techniques. Bone Marrow Transplant. 1991;8(6):429-437.

62. Smith F, Lamkin B, Versteeg C, et al. Expression of-lymphoid associated cell surface antigens by childhood acute myeloid cells lacks prognostic significance. Blood. 1992;79(9):2415-2422.

63. Vidriales B, Orfao A, Gonzales M, et al. Expression of NK and lymphoid-associated antigens in blast cells of acute myeloblastic leukemia. Leukemia. 1993;7(12):2026-2029.

64. Creutzig U, Harbott J, Sperling C, et al. Clinical significance of surface antigen expression in children with acute myeloid leukemia. Blood. 1995;86(8):3097-3108.

65. NewBU. Flow cytometry in haematology [slide show]. 2010. Available at: http://www.slideshare.net/NewBU/flow-cytometry-inhaematology?from=share_email_login3. Accessed May 25, 2011.
Pathology and Laboratory Medicine International

\section{Publish your work in this journal}

Pathology and Laboratory Medicine International is a peer-reviewed, open access journal focusing on innovative basic research and translational research related to pathology or human disease. The journal includes original research, updates, case reports, reviews and commentaries on current controversies. The Academic Sponsor

\section{Dovepress}

of this journal is the Chinese American Pathology Association (CAPA). The manuscript management system is completely online and includes a very quick and fair peer-review system. Visit http://www.dovepress.com/testimonials.php to read real quotes from published authors. 